Studies of conidial anatomy and conidiogenesis in Sporoschisma nigroseptatum ...

Wai-Hong Ho; Teik-Khiang Goh; Kevin D Hyde; I John Hodgkiss

Canadian Journal of Botany; Sep 1998; 76, 9; Academic Research Library

pg. 1614

1614

\title{
Studies of conidial anatomy and conidiogenesis in Sporoschisma nigroseptatum using light and electron microscopy
}

\author{
Wai-Hong Ho, Teik-Khiang Goh, Kevin D. Hyde, and I. John Hodgkiss
}

\begin{abstract}
The results of an ultrastructural study of the conidial anatomy and conidiogenesis in Sporoschisma nigroseptatum are presented. The development of the conidial chain involves endogenous conidial ontogeny, apical wall-building, and retrogressive conidial delimitation followed by cessation of apical wall-building, then replacement ring wall-building of additional retrogressively delimited conidia, and extrusion of the true conidial chain through the terminal aperture of the conidiogenous cell. Maturation of conidia involves deposition of two inner wall layers and formation of five distosepta. Conidial chains secede schizolytically. No proliferation of the conidiogenous cell occurs and the conidium is delimited by a cross wall that is discontinuous with the periclinal wall. Each conidium has polar plug-and-socket-like structures that are interlocked between adjacent conidia along the conidial chain. Similar plug-and-socket-like structures are also seen in other Sporoschisma species. The taxonomy of Chalara is also briefly discussed with reference to patterns of conidial wall-building.

Key words: Chalara, conidial chain, conidial ontogeny, ultrastructures.
\end{abstract}

\begin{abstract}
Résumé : Les auteurs présentent les résultats d'une étude portant sur les ultrastructures de l'anatomie des conidies et la conidiogénèse du Sporoschisma nigroseptatum. Le développement de la chaîne conidiale implique l'ontogénie endogène des conidies. le développement de la paroi apicale et la délimitation rétrogressive des conidies, suivi de l'arrêt de déposition de la paroí apicale, son remplacement par la construction de parois annulaires de conidies rétrogressivement délimitées additionnelles. et l'extrusion de la vraie chaîne de conidies à travers l'ouverture terminale de la cellule conidiogène. La maturation des conidies implique la déposition de deux couches pariétales internes et la formation de cinq distoseptations. Les chaînes conidiennnes se séparent par schizolyse. Il n'y a pas deprolifération des cellules conidiogènes et la conidie est délimitée par une paroi transverse qui est discontinue avec la paroi péricline. Chaque conidie possède un bouchon polaire et une cavité d'emboitement qui unissent les conidies adjacentes le long de la chaîne conidienne. On a également observé de telles structures à bouchons et emboîtements chez d'autres espèces de Sporoschisma. Les auteurs discutent également de la taxonomie du Chalara en relation avec la déposition du matériel pariétal.
\end{abstract}

Mots clés : Chalara, chaîne conidienne, ontogénie conidienne, ultrastructures.

[Traduit par la Rédaction]

\section{Introduction}

The genus Sporoschisma Berk. \& Broome was recently monographed by Goh et al. (1997) and currently comprises seven species, viz. Sporoschisma mirabile Berk. \& Broome (type species), Sporoschisma juvenile Boudier, Sporoschisma nigroseptatum D. Rao \& R. Rao, Sporoschisma parcicuneatum Goh \& K.D. Hyde, Sporoschisma phaeocentri W.H. Ho, K.D. Hyde \& Goh, Sporoschisma saccardoi E.W. Mason \& S. Hughes, and Sporoschisma uniseptatum Bhat. Species of

Received January 7. 1998.

W.H. Ho, ${ }^{1}$ T.K. Goh, K.D. Hyde, and I.J. Hodgkiss. Department of Ecology and Biodiversity, University of Hong Kong, Pokfulam Road. Hong Kong.

1 Author to whom all correspondence should be addressed. e-mail: who@@graduate.hku.hk
Sporoschisma are commonly found on decaying wood in ter restrial and freshwater habitats and are either pan-tropical or cosmopolitan in distribution. The genus is characterised by the production of cylindrical, pigmented phragmoconidia. densely pigmented conidiophores, and conidiogenous cells that each comprise a swollen venter and a tubular collarette (sensu Minter et al. 1982, 1983a). Successive production of conidia within the swollen venter of conidiogenous cells results in the extrusion of long conidial chains above the tubular collarettes of conidiogenous cells (Goh et al. 1997).

During a study of freshwater fungi on wood submerged in a stream in Hong Kong, we frequently collected S. nigroseptatum. In each conidium, we observed a plug-like protrusion at the distal end and a socket-like depression at the other end. Therefore, we decided to examine the ultrastructure of these conidia and their formation and these results are presented in this paper. In addition to $S$. nigroseptatum, two other species, $S$. saccardoi and an undescribed Sporoschisma sp., were examined using scanning electron microscopy. Some taxo- 
nomic notes on Sporoschisma and the closely related genus Chalara (Corda) Rabenh. are also provided.

Minter et al. (1982, 1983a, 1983b) reassessed the processes involved in conidial ontogeny and delimited seven conidiogenous events to describe the development of conidia, viz. conidial ontogeny, conidial wall-building, conidial delimitation, conidial maturation, conidial secession, conidiogenous cell proliferation, and conidiogenous cell regeneration. Their work has been accepted by some workers (e.g., Kirk 1985; Sutton 1986; Nag Raj 1993; Hawksworth et al. 1995, see "mitosporic fungi"; Goh and Hyde 1997). Their concepts and definitions of conidial development are adopted in this paper.

\section{Materials and methods}

\section{Light microscopy}

Freshly collected wood samples were incubated in plastic boxes lined with moistened paper towels and examined within 1 month. Fungal fruiting bodies were mounted on slides either in millipore filter water or lactophenol for microscopic examination.

\section{Cryo-scanning electron microscopy (Cryo-SEM)}

Freshly collected samples and dried specimens were frozen in Polaron LT7400 Cryoprep using liquid nitrogen. The specimens were subsequently sublimed at -80 to $-90^{\circ} \mathrm{C}$ for $20 \mathrm{~min}$, frozen down to $-150^{\circ} \mathrm{C}$, sputter-coated with gold for $40 \mathrm{~s}$, and examined using a Leica Cambridge Stereoscan 440 scanning electron microscope operating at $10 \mathrm{kV}$ and $-150^{\circ} \mathrm{C}$.

\section{Transmission electron microscopy (TEM)}

Freshly collected samples were embedded in $2 \%(\mathrm{w} / \mathrm{v})$ ion agar, fixed with $4 \%(\mathrm{v} / \mathrm{v})$ glutaraldehyde for $4 \mathrm{~h}$, postfixed with $2 \%(\mathrm{w} / \mathrm{v})$ osmium tetroxide at $4^{\circ} \mathrm{C}$ overnight, washed with distilled water, dehydrated through a graded alcohol series and acetone series, embedded in Möllenhauer's resin (Möllenhauer 1964), and polymerized at $60^{\circ} \mathrm{C}$ for 3 days. Ultrathin sections were stained with lead citrate for $15 \mathrm{~min}$ and poststained with uranyl acetate for $40 \mathrm{~min}$ and examined using a JEOL 100S transmission electron microscope operating at $80 \mathrm{kV}$.

\section{Material examined}

Sporoschisma nigroseptatum (TEM): HONG KONG: Tai Po Kau Forest Stream, on submerged twigs of Machilus velutina Champ., 22 March 1997, W.H. Ho WH209 (HKU(M) 6050); S. nigroseptatum (cryo-SEM): HONG KONG: Tai Po Kau Forest Stream, on submerged twig of Pinus massoniana Lamb., 27 June 1996, W.H. Ho WH209 (HKU(M) 4579): S. saccardoi (Cryo-SEM): ibid., WH10I (HKU(M) 4585): Sporoschisma sp. (Cryo-SEM): ibid., WH232 (HKU(M) 4883).

\section{Results}

\section{Light microscopy}

Immature conidia of $S$. nigroseptatum were aseptate and hyaline but had the shape of fully matured conidia (Fig. 1). The central septum (S1) was the first-formed septum (Fig. 2) followed by the two outermost septa (S2) delimiting the hyaline end cells (Fig. 3). The penultimate septa (S3) were formed last between the $\mathrm{S} 1$ and $\mathrm{S} 2$ septa (Fig. 4). Mature conidia were 5-septate with four olivaceous brown inner cells and two hyaline polar cells (rarely 7-septate: two hyaline polar cells and six pigmented inner cells, Fig. 5), with a plug-like protrusion (approximately $1.5 \mu \mathrm{m}$ wide and $0.5 \mu \mathrm{m}$ high) at the distal end and a socket-like depression at the proximal end
(Figs. 7 and 8). Individual conidia released from the conidial chains possessed a fringe comprising the remains of the conidium-delimiting cross wall at both ends (Fig. 6). Conidia usually became mature before they were extruded from the tubular collarettes of the conidiogenous cells. Mature conidia were usually longer than immature, hyaline conidia.

\section{Cryo-SEM}

The distinct plug-like protrusion at one end and the complementary depression at the other end of each conidium of $S$. nigroseptatum were also seen using SEM. The broken edge of the conidium-delimiting cross wall was visible at each end of the conidium (Fig, 9). In S. saccardoi, a minute circular depression was seen at one end of the conidium (Fig. 10). In Sporoschisma sp., a faint circular structure within an undulating circular outline was seen at the ends of the conidium (Fig. 11). The conidial walls of these Sporoschisma species were covered by a mucous layer of varying thickness (Figs. 9-11).

\section{TEM}

In $S$. nigroseptatum, two septa were visible in the conidiophores (Fig. 13). The walls of conidiophores and conidiogenous cells comprised two layers: a thick, electron-dense outer wall layer $(1.3-1.8 \mu \mathrm{m})$ and a thin, less electron-dense inner wall layer $(0.3-0.5 \mu \mathrm{m})$ (Figs. 14-17). The septa in the conidiophores contained an outer ring of electron-dense material (Fig. 17). The outer wall layers of the conidiophores and conidiogenous cells comprised fibrillar electron-dense deposits (Fig. 19). A thin discontinuous layer comprising granular electron-dense deposits (approximately $40 \mathrm{~nm}$ thick) covered the outer surfaces of the conidiophores and conidiogenous cells (Fig. 19).

Formation of conidia occurred in the swollen venters of conidiogenous cells as shown in Fig. 14. The cytoplasm of the venter comprised lipid globules, membrane profiles, and presumably membrane-bound glycogen rosettes. Strands of peripheral endoplasmic reticulum were seen near the inner wall of the venter. Lipid globules accumulated and appeared to coalesce near the conidial primordia. New wall material was incorporated and the cytoplasm extended towards the tip of the venter and the conidial primordia extended distally (Fig. 14). The conidium-delimiting cross wall, measuring up to $900 \mathrm{~nm}$ thick, was deposited centripetally in a layer, perpendicular to the axis of the conidiogenous cell. The formation of the conidium-delimiting cross wall appeared to be independent of the formation of the primary conidial wall (Figs. 14 and 15). The resulting conidium-delimiting septum was less electron dense than the periclinal conidial wall (Figs. $14,15,23,25,26$, and 28). Conidia within the tubular collarette of the conidiogenous cell were separated from the wall of the collarette by an electron-translucent layer $1-1.5 \mu \mathrm{m}$ thick (Figs, 14 and 15).

During maturation of conidia, an additional wall layer was deposited onto the inner surface of the primary conidial wall (Figs. 20 and 21). The conidial wall was transformed from the 120- to 200-nm-thick bilamellate wall (Fig. 21) into a 0.7 - to 1.4- $\mu \mathrm{m}$-thick trilamellate wall (Fig. 20). The mature trilamellate wall comprised one outer, first-formed primary wall layer and two inner, subsequently formed secondary wall layers (Fig. 20). In maturating conidia, the middle wall layer of the inner brown cells was densely laden with electron-dense 
Figs. 1-8. Light micrographs of S. nigroseptatum. Fig. 1. Hyaline, one-celled immature conidium. Fig. 2. Immature conidium with a developing central septum (S1). Note that the conidium is lightly pigmented, except at the polar regions. Fig. 3. Pale brown immature conidium with a central septum and two outer septa (S2). Fig. 4. Maturing conidium with one penultimate septum formed (S3). Fig. 5. Unusual 7-septate conidium. Fig. 6. Schizolytically detached conidium with a fringe of residual wall material shown at one end (arrowheads). Fig. 7. Mature conidia with the plug-and-socket-like structures (PG, SC). IC, inner brown cell; OC, outer hyaline cell; PC, penultimate brown cell. Fig. 8. Conidia extruding from the tubular collarette of conidiogenous cell with distinct plug-like protrusion formed at the distal end. Figs. 1-6 and 8 in lactophenol;

Fig. 7 in filtered water. Scale bars $=10 \mu \mathrm{m}$.

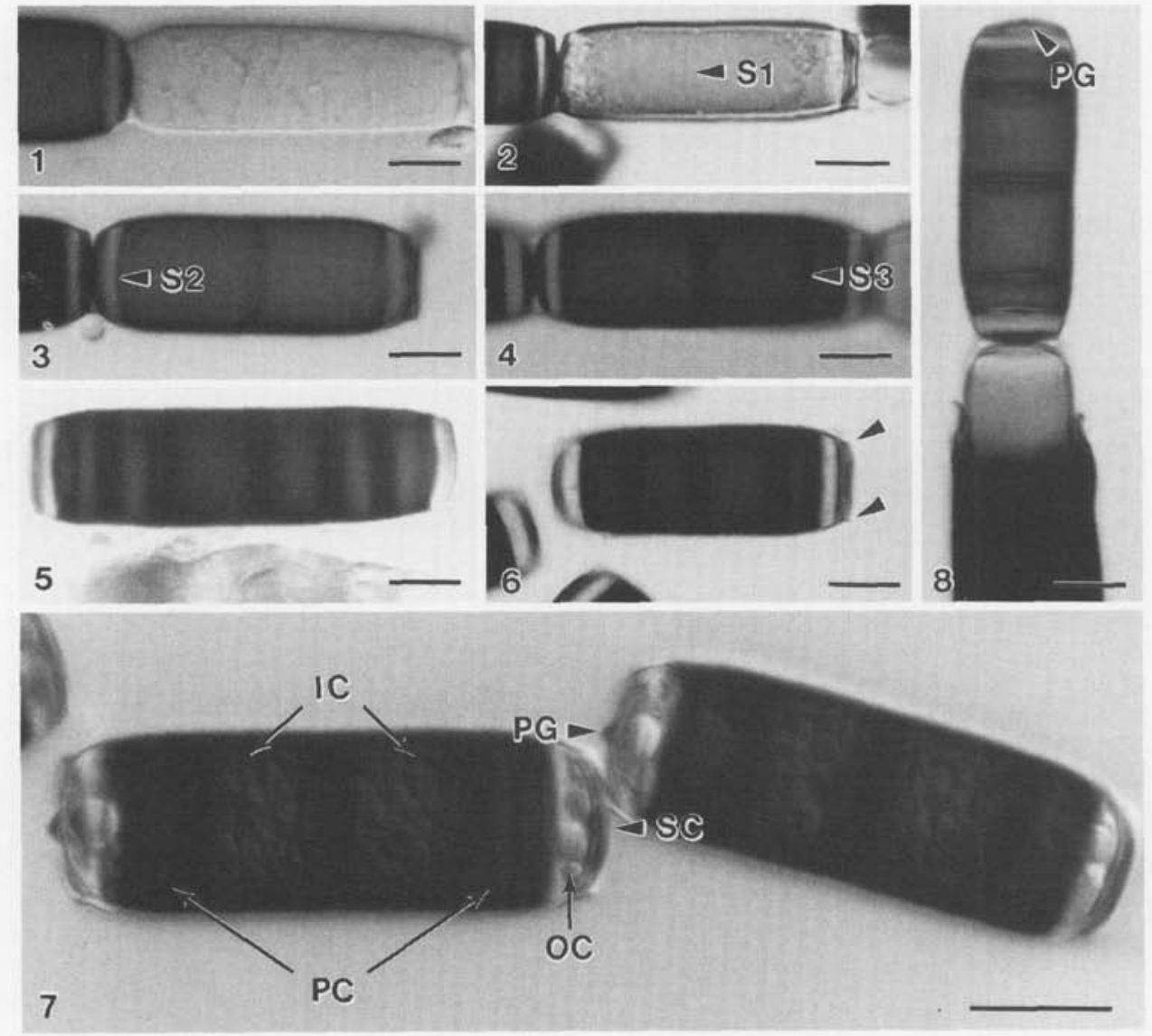

fibrillar material, which was very sparse in the hyaline polar cells (Figs. 23, 24, 26, and 27). The periclinal wall of the four central brown cells was thick $(1-1.4 \mu \mathrm{m})$, comprising a 120 to 150 -nm-thick outer layer, a 400 - to 700 -nm-thick middle layer, and a 400 - to 620 -nm-thick inner layer. The periclinal wall of the polar hyaline cells was much thinner $(700$ $750 \mathrm{~nm}$ ), with an approximately 100 -nm-thick outer layer, a 250- to 400 -nm-thick middle layer, and a 200 - to $400-\mathrm{nm}$ thick inner layer (Figs. 12, 26, and 27). The outer wall layer was continuous along the conidial chain, linking the conidia together (Figs. 23 and 26). At this stage, the conidium-delimiting cross wall sometimes lysed, more or less medially, to release individual conidia (Figs. 12 and 28).

In immature conidia, the developing central septum (S1) was thin (40-70 nm) and less electron dense (Fig. 24). At maturity, five septa were formed and they became thickened (S1 and S3 septa: 1.1-1.3 $\mu \mathrm{m}$ thick; S2 septum: approximately $0.9 \mu \mathrm{m}$ thick) (Figs. 12, 18, 26, and 27). The septa were bilamellate with an inner electron-dense wall layer and an outer, less electron-dense wall layer (Figs. 12, 18, 26, and 27). The outer, less electron-dense septal wall layer (320-
$400 \mathrm{~nm}$ thick in brown cells, 90-100 $\mathrm{nm}$ thick in hyaline cells) was continuous with the inner conidial wall layer, while the inner, electron-dense septal wall layer ( $300-450 \mathrm{~nm}$ thick) was continuous with the middle conidial wall layer (Figs. 26 and 27). The conidial septum was of the simple pore type (Fig. 22).

Each conidium had a plug-like protrusion at the distal end and a socket-like depression at the proximal end (Fig, 18). These protrusions and depressions were formed at the central pore of the conidium-delimiting septum (Figs. 12, 25, and 28). The plug-like protrusion at the apex of each conidium was plugged into the socket-like depression at the base of each adjacent conidium along the conidial chains (Fig. 12). In immature conidia, where only the central septum had been formed, the plug-like structure was up to $1.5 \mu \mathrm{m}$ in diameter, $0.4 \mu \mathrm{m}$ high, with a thin pigmented layer (approximately $150 \mathrm{~nm}$ thick) (Figs. 25 and 29). At maturity, the plug-like structure was up to $2.3 \mu \mathrm{m}$ in diameter, $0.7 \mu \mathrm{m}$ high, with a thicker electron-dense layer (approximately $500 \mathrm{~nm}$ thick) (Figs. 28 and 30). The plug-and-socket-like structures comprised two wall layers, which were in continuity with the 
Figs. 9-12. Cryo-SEM and TEM of Sporoschisma species. Fig. 9. Conidia of S. nigroseptatum with plug-and-socket-like structures at the ends and fringes of residual conidium-delimiting cross wall (arrowheads). Fig. 10. Conidium of $S$. saccardoi with a minute plug-like structure (arrowhead) and a fringe of residual conidium-delimiting cross wall (double arrowhead). Fig. 11. Conidia of Sporoschisma sp. Note that the conidia are rough walled and possess a faint circular structure (arrowhead) within an undulating circular outline. Fig. 12. TEM of a mature 5-septate conidium of S. nigroseptatum. Note the conidium-delimiting cross wall (DS), plug-like structure (PG), socket-like structure (SC), and large coalesced lipid globules (G) in each cell. IC, inner cell; OC, outer cell; PC, penultimate cell; S1, central septum; S2, outer septum; S3, penultimate septum. Scale bars $=5 \mu \mathrm{m}$.
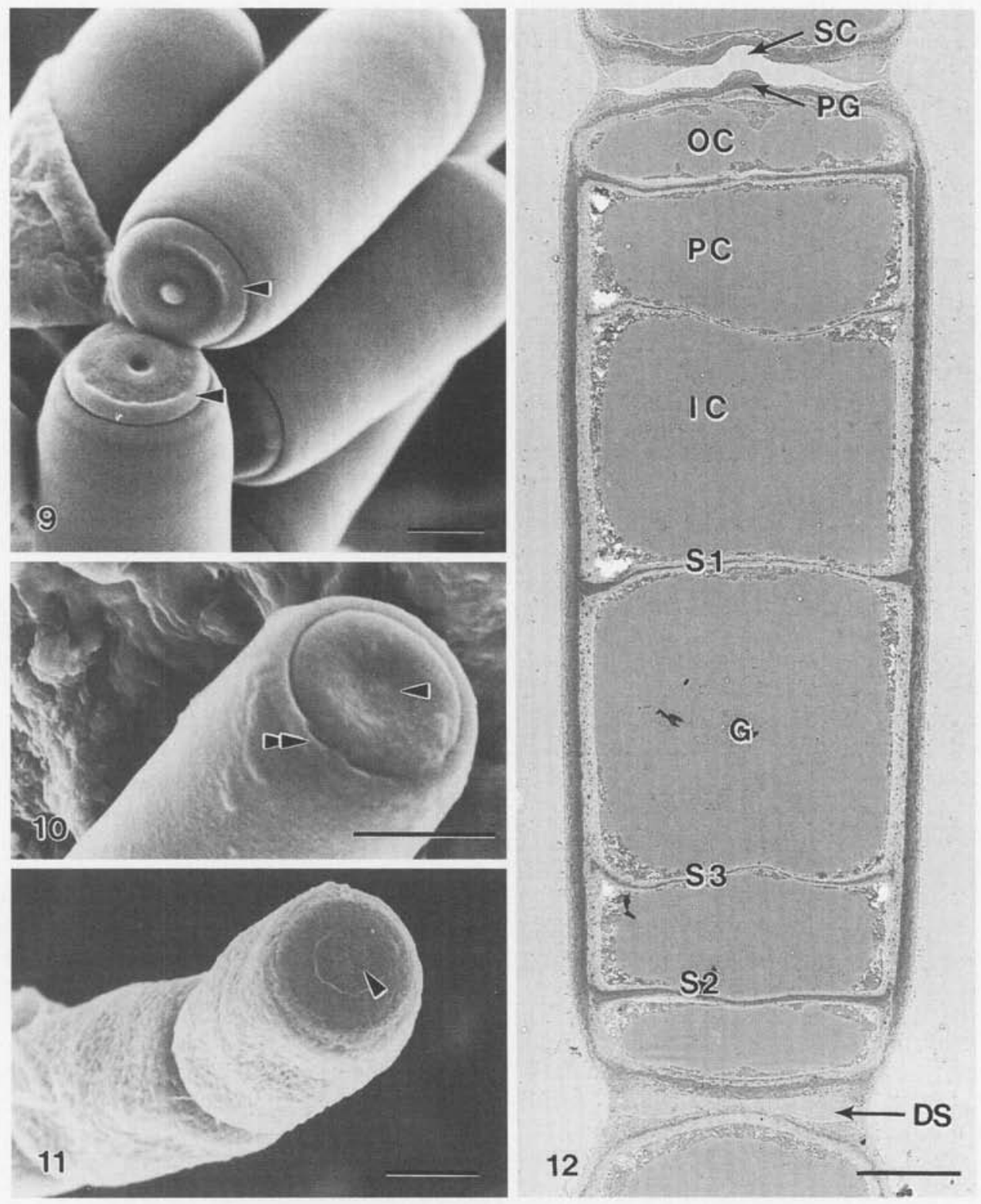

middle and the inner layer of the periclinal conidial wall, while the outer wall layer of the periclinal conidial wall was absent in this region (Figs. 29 and 30).

\section{Discussion}

\section{Conidiogenesis}

Conidiogenesis in S. nigroseptatum

Conidiogenesis in Chalara, a genus similar to Sporoschisma with species that produce conidial chains through long tubu-

lar collarettes of conidiophores, has been discussed by Nag Raj and Kendrick (1975), Hawes and Beckett (1977a, 1977b, 1977c), and Ingold (1981). Sutton and Hennebert (1994, in Hawksworth et al. 1995), who illustrated the 43 known combinations of conidiogenous (or mitosporogenous) events in the deteromycetes, described Chalara as follows: "conidial ontogeny holoblastic with new inner walls constituting the conidia laid down retrogressively by diffuse wall-building, delimitation retrogressive, loss of apical wall-building followed by replacement ring wall-building at the base of the conidiogenous cell adding more retrogressively delimited 
Figs. 13-19. TEM of longitudinal sections of the conidiophores and conidiogenous cells of S. nigroseptatum. Fig. 13. Section illustrating the tubular collarette of conidiogenous cell (CR), the swollen venter of conidiogenous cell (SV), and 2-septate (S) conidiophore (CP). Fig. 14. Section through the swollen venter of a conidiogenous cell. Note that the lipid globules $(G)$ have accumulated towards the polar end of the venter. Note the point of attachment (double arrowhead) where the primary conidial wall (CW) attaches to the venter wall. An additional less electron-dense wall layer that separates the conidial wall and the wall layer of the tubular collarette is also visible (arrowhead). DS, conidiumdelimiting septum; ER, endoplasmic reticulum; GR, presumably glycogen rosettes; MP, membrane profiles. Fig. 15. Median longitudinal section through the conidium-delimiting septum in Fig. 14. Fig. 16. Higher magnification of Fig. 13 at the lower septum of the conidiophore. illustrating the inner, less electron-dense wall layer (IL) of the conidiophore that constitutes the septum. OL, outer wall layer. Fig. 17. Section through a part of a conidiophore at a similar position as in Fig. 16. Note the amorphous electron-dense deposits (DD) at the sides of the septum. Fig. 18. Mature conidium at the mouth of the conidiogenous cell. Note that the plug-like protrusion (PG) of the conidium is positioned at the distal end. Fig. 19. Higher magnification of the conidiogenous cell wall. Note the fibrillar electron-dense deposits (FD) embedded in the outer wall layer and the electron-dense deposits on the outer surface of the wall layer. Scale bars $=10 \mu \mathrm{m}$ in Fig. 13,5 $\mathrm{m}$ in Figs. 14-18, and $1 \mu \mathrm{m}$ in Fig. 19.

conidia, the outer (original) conidiogenous cell wall breaks as a connected chain of conidia is formed, collarette variable, one locus per conidiogenous cell, secession schizolytic." The conidiogenous events in $S$. nigroseptatum are best described under this category. Regeneration of conidiogenous cells, omitted in Sutton and Hennebert's (1994, in Hawksworth et al. 1995) description, has not been observed in species of Sporoschisma, although we have observed capitate setae produced from torn tubular collarettes of aged conidiogenous cells in culture.

\section{Conidiogenesis in Chalara and Sporoschisma and types of septation}

Minter et al. (1982, 1983a) pointed out that in Chalara species, conidiogenous cells do not proliferate (as in other fungi with true-chain phialides, sensu Minter et al. 1982, $1983 a, 1983 b$ ) and a discrete event of conidial maturation is usually absent. Furthermore, the conidium-delimiting septum in Chalara species is a distoseptum (sensu Hawksworth et al. 1995), and both the inner and outer conidial wall layers are laid down within the hypothetical wall-building ring (Minter et al. 1982, 1983a). Sporoschisma nigroseptatum is similar to Chalara species in that no proliferation in the conidiogenous cell occurs. It differs from Chalara species because $(i)$ only the outer primary conidial wall layer is formed within the hypothetical wall-building ring (Fig. 14), (ii) two additional wall layers are deposited onto the inner surface of the primary conidial wall, after the conidium is delimited (Figs. 12, 18, 20, and 21), i.e., conidial maturation occurs, and (iii) the formation of the conidium-delimiting septum appears to be independent of the formation of the periclinal conidial wall (Figs. 14 and 15). The conidiumdelimiting septum in S. nigroseptatum not only differs from those of Chalara species, it also differs from the conventional concepts of euseptum (i.e., a cell-separating structure comprising multilayered walls that are structurally similar to the lateral wall; Hawksworth et al. 1995) and distoseptum (i.e., a cell-separating structure with the individual cells each surrounded by a sac-like wall layer distinct from the outer wall; Hawksworth et al. 1995). This conidium-delimiting septum is neither structurally similar to the lateral wall nor surrounded by a sac-like wall layer. It is a cross wall created by de novo synthesis within the cell. Ultrastructural studies are needed to examine the delimiting septa, cross walls, and similar structures in other mitosporic fungi before it is possi- ble to conclude whether the conidium-delimiting septum in Sporoschisma represents a unique type of septum.

\section{Origin of the conidial wall}

There are three major modes of conidium development in deuteromycetes, viz. holoblastic, enteroblastic, and thallic (Kendrick 1971). In describing the origin of conidium wall, Hennebert and Sutton (1994) proposed three additional terms, viz. "endogenous," "hologenous" (cf. holoblastic), and "enterogenous" (cf. enteroblastic). The conidium is hologenous when outer and inner wall layers of conidiogenous cell and conidium are continuous, enterogenous when the inner wall layer of the conidiogenous cell forms the outer wall of the conidium, and endogenous when no wall layers are continuous between the conidium and the conidiogenous cell (Hennebert and Sutton 1994). Coincidentally, Tiedt (1993) introduced "endoblastic" to describe conidium development in Aspergillus niger Tiegh. where none of the phialide wall layers are involved in the formation of new conidial wall layers during conidial maturation. In Chalara (Hawes and Beckett $1977 b$ ) and S. nigroseptatum, the primary conidial wall is formed by de novo synthesis, in which wall material is deposited within the inner surface of conidiophore wall. In other words, no conidiophore wall layers are involved in the formation of the primary conidial wall. In this sense, the conidial ontogeny in Chalara and S. nigroseptatum is of the endoblastic type (sensu Tiedt 1993), i.e., "endogenous wall formation" (sensu Hennebert and Sutton 1994), rather than "holoblastic" conidial ontogeny, or hologenous wall formation as described by Sutton and Hennebert (1994, in Hawksworth et al. 1995).

\section{Conidial chains}

For describing conidial chains, Minter et al. (1982, 1983a, $1983 b$ ) adopted the terms "true conidial chains" (in which there is a continuity of wall layer(s) along the conidial chains) and "false conidial chains" (in which there is no continuity of wall layers in the chains), as introduced by Subramanian (1972). Minter et al. (1983a) also proposed two additional terms, "with connectives" and "without connectives," to replace the terms "connected conidial chains" and "disconnected conidial chains" (Gams 1978), respectively. In $S$. nigroseptatum, the conidium-delimiting cross wall can be treated as with connectives (Fig. 12). Its conidial chain could be considered a true-chain type (Minter et al. 1982) because 

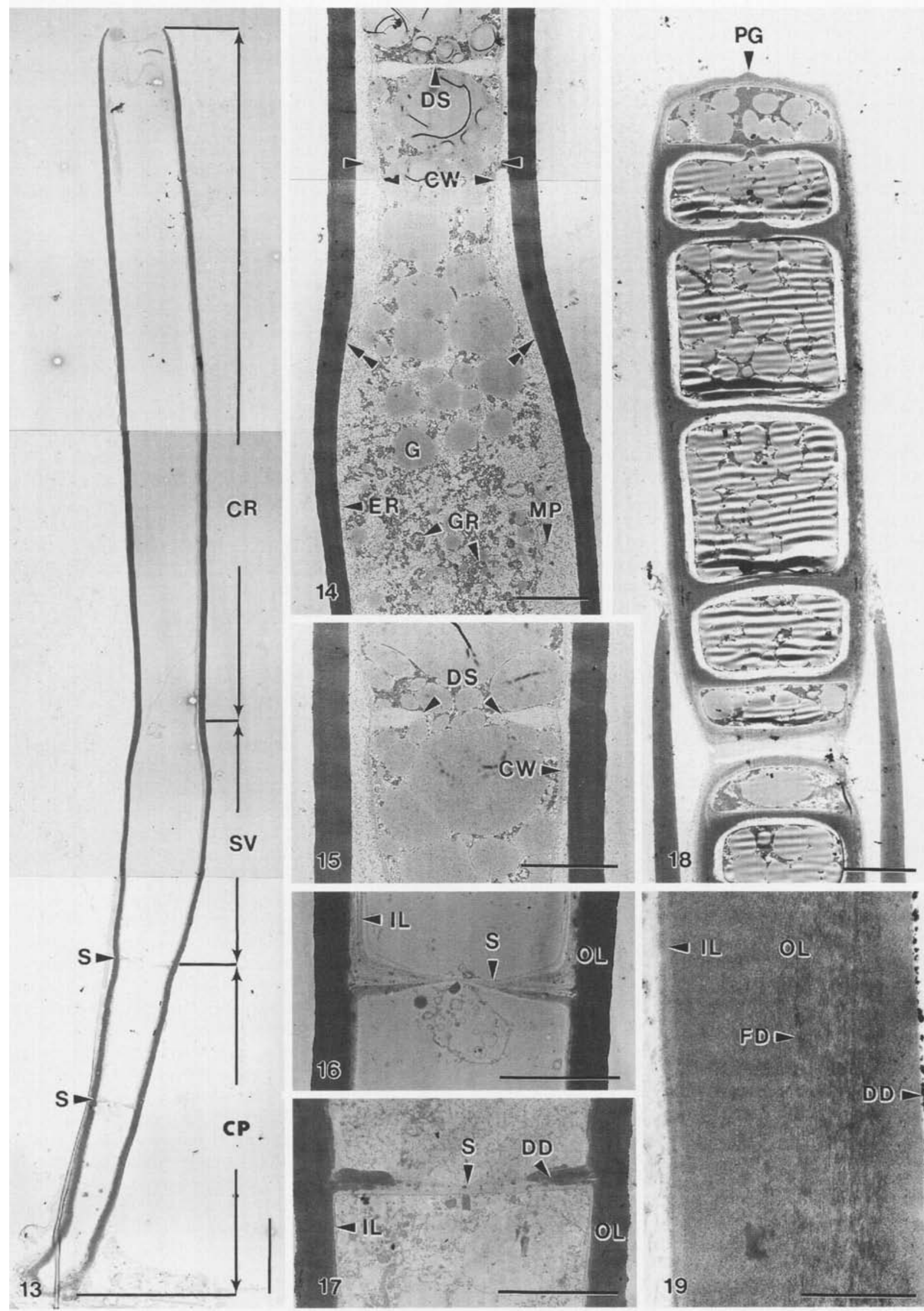

ל.
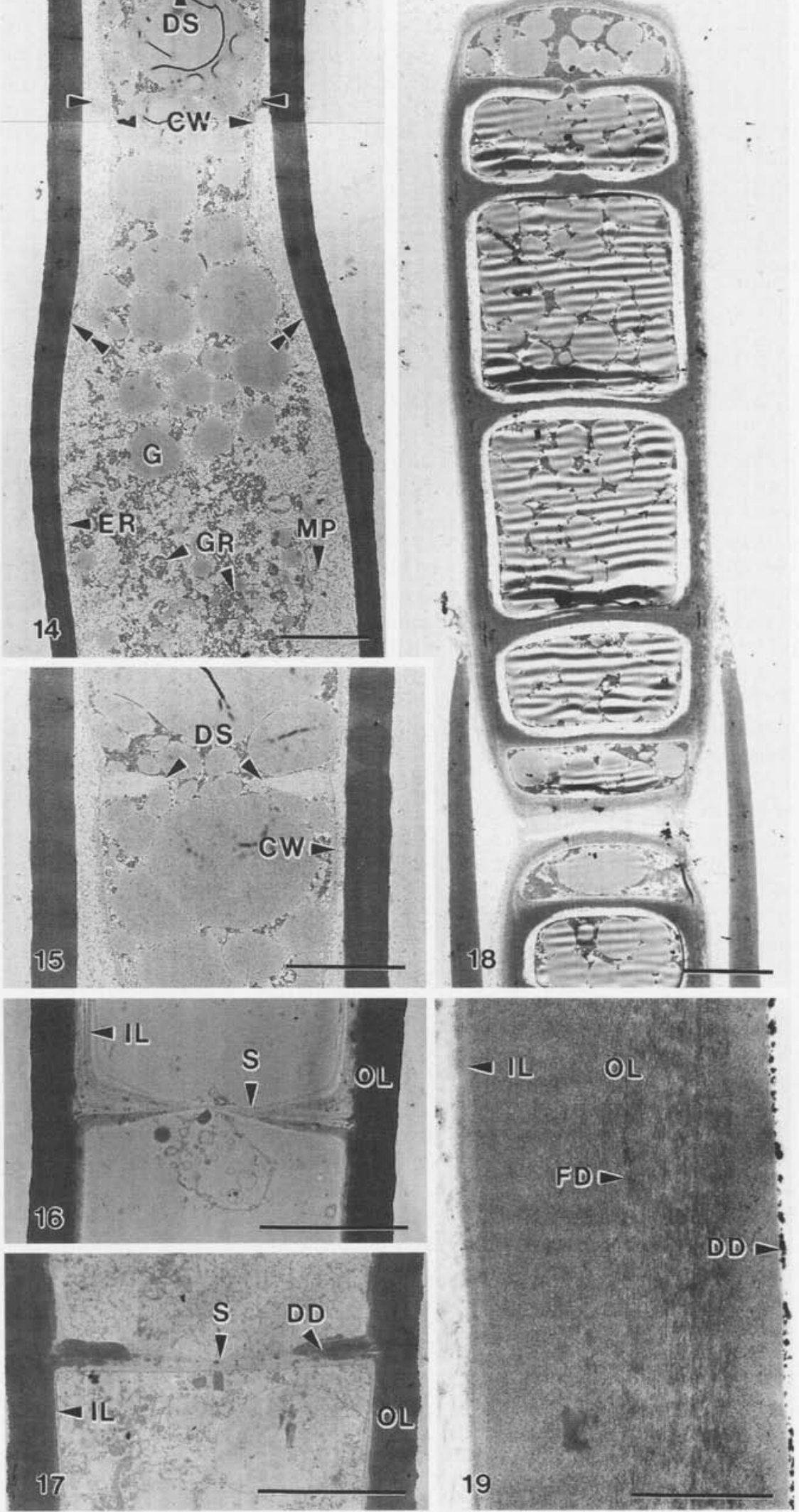
Figs. 20-30. TEM of longitudinal sections at different stages of the conidial development in S. nigroseptatum. Fig. 20. Mature conidial wall. Note the thick, middle. electron-dense amorphous wall layer (ML) embedded with fibrillar electron-dense deposits, positioned between the inner wall layer (IL) and the outer wall layer (OL). Fig. 21. Developing conidial wall with mucilaginous substance (MS), inner wall layer, and outer wall layer. Fig. 22. Section illustrating septal pore, inner septal layer (IS), and outer septal layer (OS). Figs. 23 and 26. Polar region of immature (Fig. 23) and mature (Fig. 26) conidia. Note the thickened layer of the conidium-delimiting septum (DS) between conidia and the outer wall layer, which is continuous between adjacent conidia. Also note the electron-dense middle wall layer, which is thinner at the periclinal wall of the polar cells. The outer septum (S1) of the mature conidium is bilamellate (Fig. 26). Figs. 24 and 27 . Middle region of immature (Fig. 24) and mature (Fig. 27) conidia illustrating the central septum (S3). The central septum is derived from the inner wall layer and becomes bilamellate at maturity. Figs. 25 and 29. Immature conidia with a plug-like protrusion (PG) joining to the socket-like depression (SC) of an adjacent mature conidium. Note that only the inner and the middle wall layers of the periclinal conidial wall are found at both ends of the conidia. Figs. 28 and 30. Mature conidia with plug-and-socket-like structures. Note that the conidium-delimiting septum lyses longitudinally and the outer wall layer of the periclinal conidial wall is absent at both ends of the conidia. Scale bars $=0.5 \mu \mathrm{m}$ in Figs. 20-22 and $1 \mu \mathrm{m}$ in Figs. 23-30.

(i) the primary conidial wall is a continuous wall layer (Fig. 14) and (ii) this wall layer, which later becomes the outer conidial wall layer, apparently retains its continuity at maturity (Figs. 23 and 26 ).

In summary, the developmental process of the conidial chains in $S$. nigroseptatum can be described as follows: endogenous conidial ontogeny, with primary conidial walls formed by de novo synthesis and apical wall-building (sensu Hawksworth et al. 1995; Fig. 32A), followed by retrogressive delimitation; apical wall-building then ceases and is replaced by ring wall-building at the base of the conidiogenous cell, adding more retrogressively delimited conidia (sensu Hawksworth et al. 1995; Fig. 32B). The outer (original) conidiogenous cell wall breaks as a true conidial chain is formed (Fig. 32C). Maturation of conidia involves deposition of two inner wall layers, formation of five distosepta (progressively S1, S2, and then S3 septa; Figs. 1-4, 7, and 31), and formation of plug-and-socket-like structures at the poles (Figs. 7, 12, and 31). Conidia in chains secede schizolytically (Figs. 7, 12, 25, and 28 ) and with a fringe of residual conidium-delimiting cross wall material at each end (Figs. 6, 9, and 12).

\section{Plug-and-socket-like structures}

Among the known species of Sporoschisma (Goh et al. 1997), $S$. nigroseptatum is the only species that has conidial polar structures that can be observed using light microscopy. Although this species has been frequently recorded in various countries, including Australia, Costa Rico, Hong Kong, India, Japan, and New Zealand (Rao and Rao 1964; Hughes 1966; Morris 1972; Goh et al. 1997), the structure has never been described. The SEM of $S$, saccardoi published by Nakagiri and Ito (1995) illustrates a minute, socket-like depression on a conidium, but this structure was not discussed.

It is unknown whether a similar mechanism of holding conidia in chains exists in other mitosporic genera. Other than Sporoschisma, many hyphomycetes genera produce chains of cylindrical, cuneiform, or fusiform conidia in a phialidic manner extruding from the tubular collarettes of conidiogenous cells or conidiophores. These include Ascoconidium Seaver, Chaetochalara B.C. Sutton \& Piroz., Chalara (Corda) Rabenh., Chalaropsis Peyronel, Fusichalara S. Hughes \& Nag Raj, Phialocephala W.B. Kendr., Phialophora sect. Catenulatae W. Gams, Sporendocladia G. Arnaud ex Nag Raj \& W.B. Kendr., and Sporoschismopsis Hol.-Jech. \& Hennebert (Ellis 1971, 1976; Carmichael et al.
1980). On the other hand, isthmospores produced by genera such as Speiropsis and Wiesneriomyces are reported as being capable of seceding, although with difficulty, at the constricted region of the conidia (Ellis 1976). Other hyphomycetes, including some species of Acremonium Link and Monocillium S.B. Saksena, produce globular conidia with a nipple-shaped protrusion that links to adjacent conidia in the conidial chain (Carmichael et al. 1980; Matsushima 1985). Whether these hyphomycetes possess mechanisms similar to those of $S$. nigroseptatum for holding individual conidia together is not known. Further examination of these fungi using light and electron microscopy are necessary.

\section{Taxonomic notes}

Wingfield et al. (1995) demonstrated that a Chalara-like taxon exhibited conidial development by apical wallbuilding, resulting in a discontinuous outer wall layer between adjacent conidia (i.e., false-chain type) and a fringe of the wall layer existing only at the proximal end of the conidia. In contrast, Sporoschisma and Chalara species produce conidia by ring wall-building, resulting in a continuous wall layer between adjacent conidia (i.e., true-chain type) with a fringe of septum material at both ends of the conidia (Hawes and Beckett 1977b; Minter et al. 1982, 1983a, $1983 b$ ). Wingfield et al. (1995) did not place their taxon in the genus Chalara because of the different wall-building pattern and it remained unnamed. However, some Chalara-like taxa with only a basal fringe of wall material are still accepted as species of Chalara (e.g., Chalara angustata Kowalski \& Halmschlager, 1996). We agree with Wingfield et al. (1995; also Subramanian 1972) that the wall-building type of conidial development could be used as an important feature in delimiting genera of hyphomycetes. A new genus is probably needed to accommodate the Chalara-like species with apical wall-building.

Sporoschisma saccardoi is morphologically similar to $S$. nigroseptatum. The former is conventionally distinguished from the latter in having conidia with four inner cells of about equal size and with narrower black septal bands (Nag Raj and Kendrick 1975). Nakagiri and Ito (1995), however, demonstrated that these characters are inconsistent both in culture and on natural substrates. Using light microscopy, we have observed that conidia of $S$. nigroseptatum consistently possess distinct plug-and-socket-like structures at the ends, while those of $S$. saccardoi do not. We consider this is a helpful 


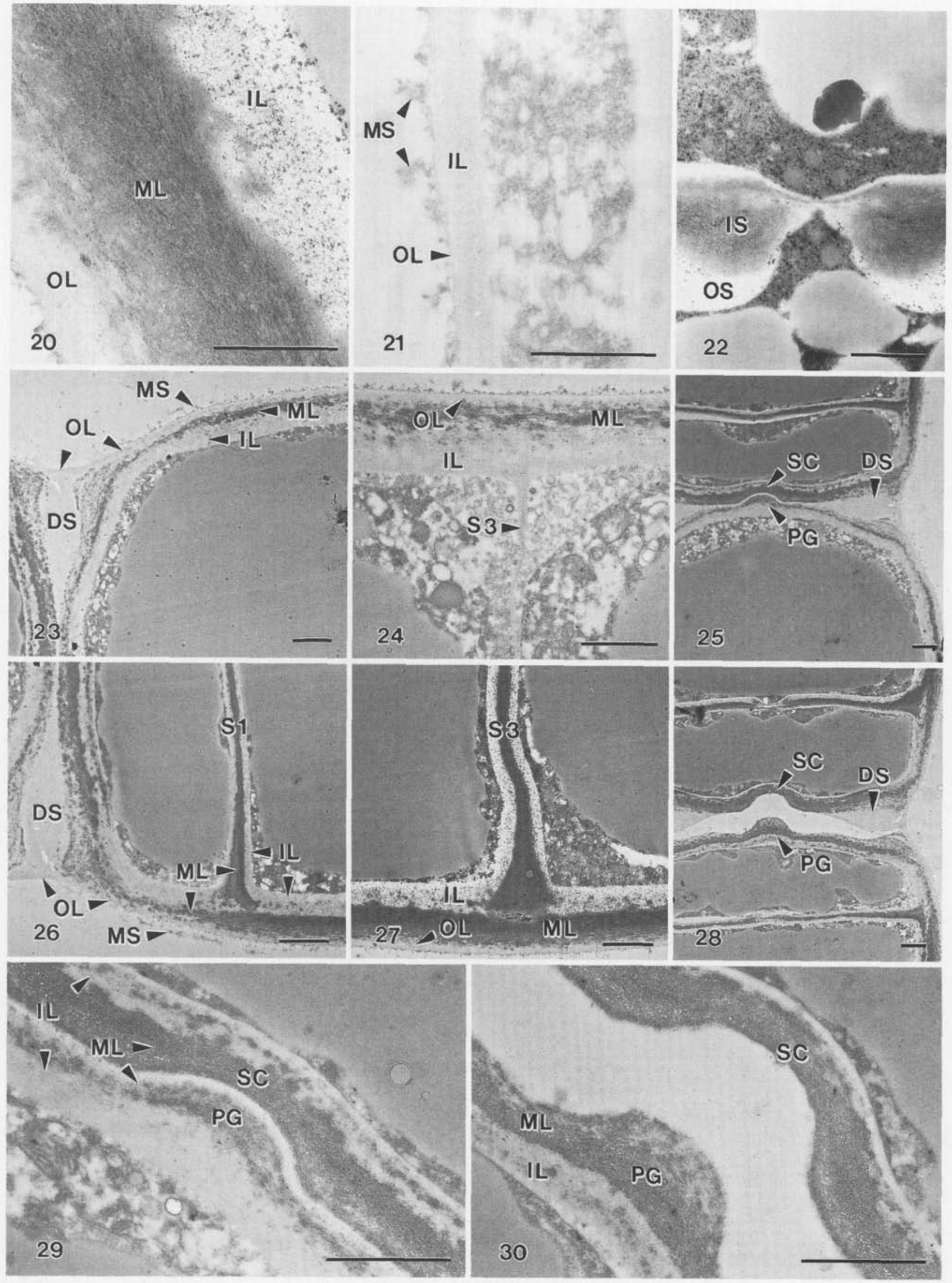


Figs. 31 and 32. Diagrammatic interpretations of the different developmental stages of the conidia, conidiogenous cells, and conidiophores of $S$. nigroseptatum. Fig. 31. Development of conidia in true conidial chains. (A-F) Progressive developmental stages of conidia in chains (Fig. 31A being at the earliest stage and Figs. $31 \mathrm{E}$ and $31 \mathrm{~F}$ being at the latest stage) illustrating outer wall layer (OL), middle wall layer (ML), inner wall layer (IL), outer septal layer (OS), inner septal layer (IS), plug-like structure (PG), socket-like structure (SC), and conidium-delimiting septum (DS). Fig. 32. Development of conidial chains within conidiogenous cells. (A) Young conidiophore and conidiogenous cell with hypothesized apical wall-building (AWB). Primary conidial wall (asterisk) and conidium-delimiting septum formed by de novo synthesis. (B) Mature conidiophore and conidiogenous cell with retrogressively formed conidium-delimiting septum, and ring wall-building (RWB) replacing apical wallbuilding. (C) Mature conidiophore and conidiogenous cell. The tip of the conidiogenous cell wall breaks as the conidial chain is formed progressively by ring wall-building. $\mathrm{AL}$, additional wall layer; $\mathrm{CW}$, conidial wall; $\mathrm{PW}$, conidiogenous cell wall; $\mathrm{S}$, septum.

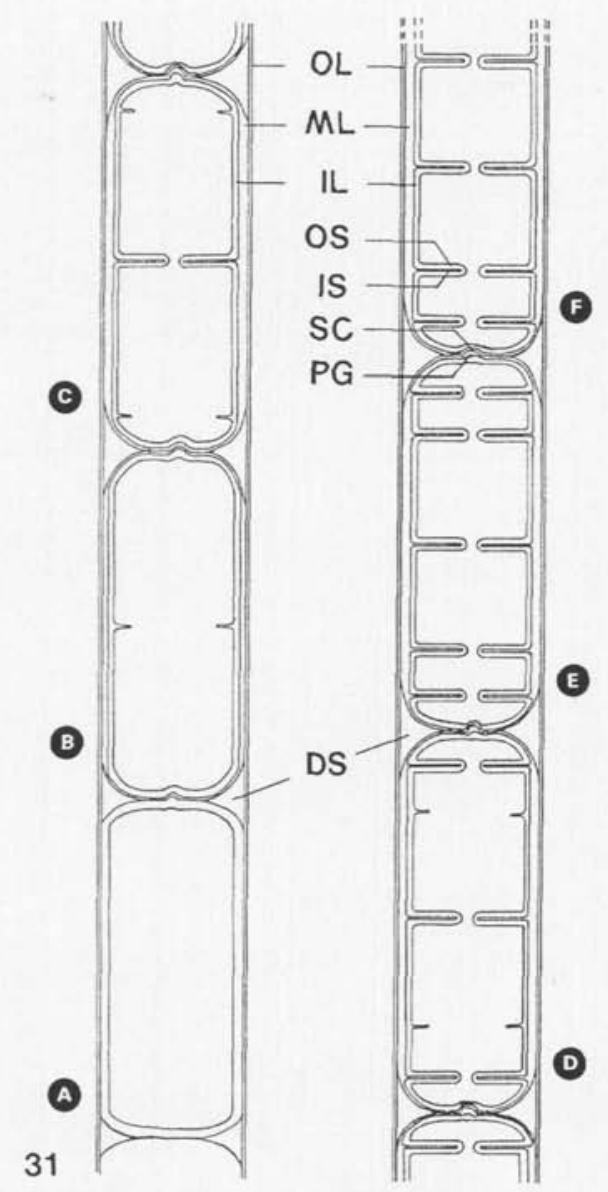

32

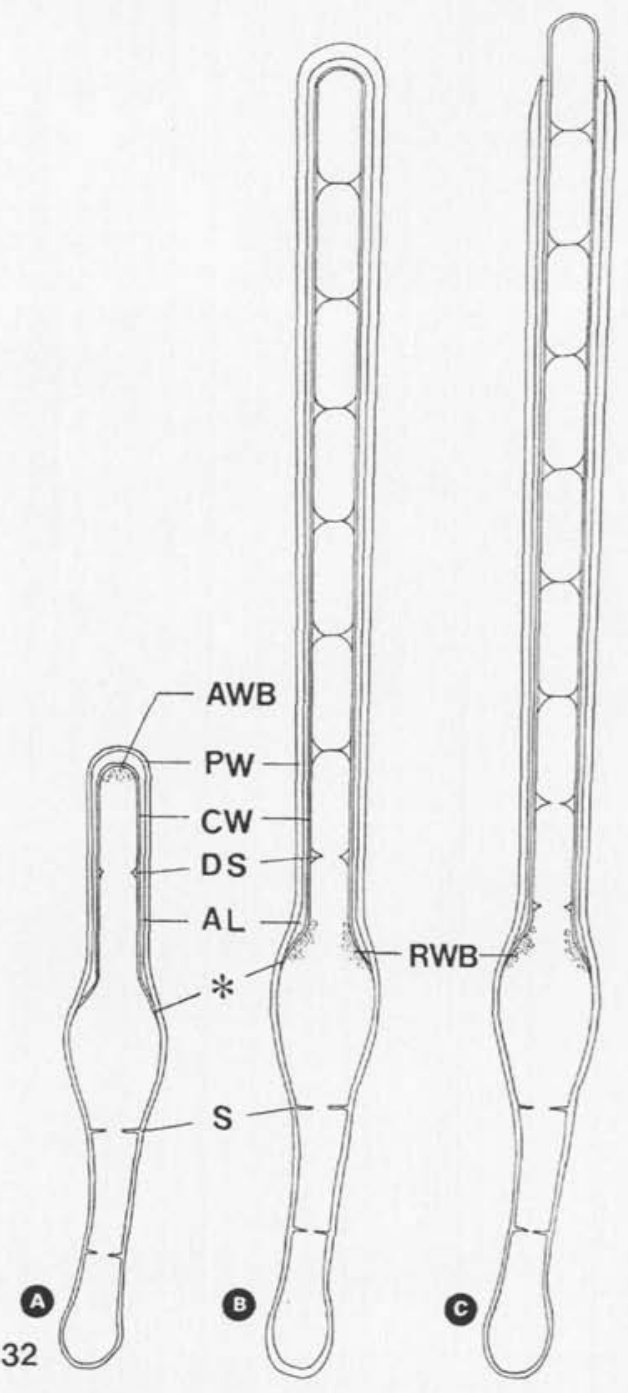

character to further distinguish these two morphologically similar species.

\section{Acknowledgements}

We are grateful to S.W. Wong for his valuable comments on this work. Thanks are also extended to H.Y.M. Leung, the Electron Microscopy Unit of the Queen Mary Hospital, and the Photngraphic Unit of the Science Faculty, University of Hong Kong, for technical and photographic assistance. W.H. Ho also thanks the University of Hong Kong for the award of a postgraduate studentship.

\section{References}

Carmichael, J.W., Kendrick, W.B., Conners, I.L., and Sigler, L. 1980. Genera of Hyphomycetes. University of Alberta Press, Edmonton, Alta.

Ellis, M.B. 1971. Dematiaceous Hyphomycetes. Commonwealth Mycological Institute, Kew, Surrey, U.K.

Ellis, M.B. 1976. More dematiaceous Hyphomycetes. Commonwealth Mycological Institute, Kew. Surrey, U.K.

Gams, W. 1978. Connected and disconnected chains of phialoconidia and Sagenomella gen.nov. segregated from Acremonium. Persoonia, 10: 97-112.

Goh, T.K., and Hyde, K.D. 1998. A new hyphomycetes genus 
Conioscyphopsis from wood submerged in a freshwater stream and a review of the genus Conioscypha. Mycol. Res. 102: 308312.

Goh. T.K., Ho. W.H., Hyde, K.D., and Umali, T.E. 1997. New records and species of Sporoschisma and Sporoschismopsis from submerged wood in the tropics. Mycol. Res. 101: 1295-1307.

Hawes, C.R., and Beckett, A. 1977a. Conidium ontogeny in the Chalara state of Ceratocystis adiposa. I. Light microscopy. Trans. Br. Mycol. Soc. 68: 259-265.

Hawes, C.R.. and Beckett, A. 1977b. Conidium ontogeny in the Chalara state of Ceratocystis adiposa. II. Electron microscopy. Trans. Br. Mycol. Soc. 68: 267-276.

Hawes, C.R., and Beckett, A. $1977 \mathrm{c}$. Conidium ontogeny in Thielaviopsis basicola. Trans. Br. Mycol. Soc. 68: 304-307.

Hawksworth, D.L., Kirk, P.M. , Sutton, B.C., and Pegler, D.N. 1995. Ainsworth \& Bisby's dictionary of the fungi. 8th ed. CAB International. Wallingford, U.K.

Hennebert. G.L., and Sutton, B.C. 1994. Unitary parameters in conidiogenesis. In Ascomycete systematics: problems and perspectives in the nineties. Edited by D.L. Hawksworth. NATO ASI (Adv. Sci. Inst.) Ser. Ser. A Life Sci. 269; 65-76.

Hughes. S.J. 1966. New Zealand fungi. 6. Sporoschisma Berk, and Br. N.Z. J. Bot. 4: 77-85.

Ingold. C.T. 1981. The first-formed phialoconidium of Thielaviopsis basicola. Trans. Br. Mycol. Soc. 76: 517-519.

Kendrick, W.B. 1971. Taxonomy of Fungi Imperfecti. University of Toronto Press, Toronto, Ont.

Kirk, P.M. 1985. New or interesting microfungi. XIV. Dematiaceous hyphomycetes from Mt Kenya. Mycotaxon, 23: 305-352.

Kowalski. T., and Halmschlager, E. 1996. Chalara angustata sp.nov. from roots of Quercus petraea and Quercus robur. Mycol. Res. 100: $1112-1116$.

Matsushima, T. 1985. Matsushima mycological memoirs No. 4. Matsushima, Kobe, Japan.

Minter. D.W., Kirk, P.M., and Sutton, B.C. 1982. Holoblastic phialides. Trans. Br. Mycol. Soc. 79: 75-93.
Minter, D.W., Kirk, P.M., and Sutton, B.C. 1983a. Thallic phialides. Trans. Br. Mycol. Soc. 80: 39-66.

Minter, D.W., Sutton, B.C., and Brady, B.L. 1983b. What are phialides anyway? Trans. Br. Mycol. Soc. 81: 109-120.

Möllenhauer, H.H. 1964. Plastic embedding mixtures for use in electron microscopy. Stain Technol. 39: 111-114.

Morris, E.F. 1972. Costa Rican Hyphomycetes. Mycologia, 64: 887896.

Nag Raj, T.R. 1993. Coelomycetous anamorphs with appendagebearing conidia. Mycologue Publications, Sydney, B.C.

Nag Raj, T.R., and Kendrick, W.B. 1975. A monograph of Chalara and allied genera. Wilfrid Laurier University Press, Waterloo, Ont.

Nakagiri, A., and Ito, T. 1995. Some dematiaceous hyphomycetes on decomposing leaves of Satakentia liukiuensis from Ishigaki Island, Japan. Inst. Ferment. Res. Comm. (Osaka), 17: 75-98.

Rao, D., and Rao, P.R. 1964. Sporoschisma Berk. \& Br. from India. Mycopathol. Mycol. Appl. 24: 81-84.

Subramanian, C.V. 1972. Conidial chains, their nature and significance in the taxonomy of Hyphomycetes. Curr. Sci. 41: 43-49.

Sutton, B.C. 1986. Presidential address: improvizations on conidial themes. Trans. Br. Mycol. Soc. 86: 1-38.

Sutton, B.C., and Hennebert, G.L. 1994. Interconnections amongst anamorph and their possible contribution to ascomycete systematics. In Ascomycete systematics: problems and perspectives in the nineties. Edited by D.L. Hawksworth. NATO ASI (Adv. Sci. Inst.) Ser. Ser. A Life Sci. 269: 77-100.

Tiedt, L.R. 1993. An electron microscope study of conidiogenesis and wall formation of conidia of Aspergillus niger. Mycol. Res. 97: 1459-1462.

Wingfield, M.J., Benade, E., van Wyk, P.S., and Visser, C. 1995. Conidium development in Ceratocystis autographa. Mycol. Res. 99: 1289-1294. 